\title{
Biodiversity in South African fynbos and Mediterranean heathland
}

\author{
Ojeda, Fernando ${ }^{1 *}$; Simmons, Mark T. ${ }^{2,4}$; Arroyo, Juan $^{1}$; Marañón, Teodoro ${ }^{3}$ \\ \& Cowling, Richard M. ${ }^{2,5}$
}

\begin{abstract}
${ }^{1}$ Depto. Biología Vegetal y Ecología, Universidad de Sevilla, Apdo. 1095, E-41080 Sevilla, Spain; ${ }^{2}$ Institute for Plant Conservation, University of Cape Town, 7701 Rondebosch, South Africa; and ${ }^{3}$ IRNAS-CSIC, Apdo. 1052, E-41080 Sevilla, Spain; ${ }^{4}$ Present address: Lady Bird Johnson Wildflower Center, 4801 La Crosse Avenue, Austin, TX 78739-1702, USA; ${ }^{5}$ Present address: Terrestrial Ecological Research Unit, Department of Botany, University of Port Elizabeth, P.O. Box 1600, Port Elizabeth 6001, South Africa. ${ }^{*}$ Corresponding author; Present address: Depto. de Biología, CASEM, Universidad de Cádiz, Pol. Río San Pedro s/n, 11510-Puerto Real, Spain; Fax+34956016019; E-mail fernando.ojeda@uca.es
\end{abstract}

\begin{abstract}
The theory of convergence predicts that, given similar selective regimes, both present and past, unrelated ecological communities will show similar attributes. Mild Pleistocene climate, highly infertile soils, and similar fire regimes explain the remarkable convergence between mediterranean-type vegetation from South Africa (fynbos) and Australia (kwongan). Heathlands in the Aljibe Mountains, at the western end of the Mediterranean basin, constitute a single vegetation type within the Mediterranean region.

We studied the association between endemism and plant life form in a flora from environmentally similar areas of the South African Cape region (fynbos) and the Aljibe Mountains by contingency table analysis. We included two non-acid, neighbouring areas to the latter region in the analysis as contrasts. We also compared the patterns of variation in three components of biodiversity (species richness, endemism level and taxonomic singularity) of fynbos and Aljibe heathland woody plant communities along similar soil fertility gradients by means of two-way ANOVAs.

At the regional (flora) level, our results show two common features in the biological aspects of endemism between the two regions: (1) edaphic endemism and (2) association of endemism with the shrub growth form. At the community level, we detected strong similarities in the patterns of variation of endemism and taxonomic singularity of woody communities from both regions along an ecological gradient related to soil fertility. We interpret these similarities, both at the regional and community levels, as suggestive of convergence between fynbos and Aljibe heathland.
\end{abstract}

Keywords: Acid soil; Aljibe; Convergence; Diversity; Edaphic endemism; Mountain; Strait of Gibraltar; Cape floristic region.

\section{Introduction}

Ecosystem convergence has been considered by many ecologists as clear evidence of the relevance of ecological processes (i.e. response of species to present environmental conditions and interactions among co-occurring species) in the structure, function, and organization of communities (e.g. Milewski 1983). Nevertheless, past historical events also play a crucial role in explaining structural and functional features (Peet 1978; Herrera 1992) and diversity patterns (Schluter \& Ricklefs 1993; Cowling et al. 1994).

Since Cody \& Mooney published their (now) classic paper (1978) on convergence in mediterranean-climate ecosystems, a large amount of research has been conducted on the ecology of different mediterranean vegetation types, especially on between-region comparisons of ecological and evolutionary patterns and processes (e.g. Naveh \& Whittaker 1979; Shmida 1981; Cowling et al. 1994). For instance, a mild Pleistocene climate, highly infertile soils and similar fire regimes have been invoked as the selective regime shared by South African fynbos and Australian kwongan, which may explain the remarkable convergence between these Gondwanan, mediterranean-climate ecosystems (Cowling et al. 1994, 1996). In contrast, richer soils and more pronounced Pleistocene climate changes in the Mediterranean Basin and California would explain the lack of convergence between these two mediterranean regions from the Northern Hemisphere and the Gondwanan ones (Cowling et al. 1996). However, the largest mediterranean-type region, the Mediterranean Basin, is heterogeneous and therefore difficult to characterize in terms of these features.

The South African Cape region has long been recognized as one of the world's most diverse areas due to its high plant species richness and endemism (Goldblatt 1997). This region's most characteristic vegetation type is fynbos (Bond \& Goldblatt 1984) which is a local 
name for a heathland-like vegetation (Moll 1991). Poor, sandstone-derived soils, mild or semi-mediterranean climate and recurring fires are the main environmental features of fynbos (Cowling 1992). The Pleistocene climate was humid and, at least in the western half of this region, mild (Cowling et al. 1999).

Heathlands in the Aljibe Mountains ('Aljibe') near Gibraltar (Fig. 1) constitute a singular vegetation type in the Mediterranean Basin (Arroyo \& Marañón 1990; Ojeda et al. 2000a). Acid, nutrient-poor soils, mainly derived from Oligo-Miocenic sandstone, and a relatively mild mediterranean climate are responsible for the relatively high species richness and levels of endemism of these heathlands (Ojeda et al. 1995, 1996, 2000a). Summer wildfires are also frequent (Ibarra 1993). Furthermore, Pleistocene glacial conditions would have been alleviated in this region as a result of strong maritime influence owing to its geographical position (see Fig. 1). This is reflected in the abundance of relict Tertiary plant taxa (e.g. Rhododendron ponticum, Prunus lusitanica, Laurus nobilis and many fern species; RivasGoday 1968; Ojeda et al. 1996, 2000a).

In this article, we present the results of a comparative analysis of biodiversity patterns between South African fynbos and Aljibe heathlands at both regional flora and community levels. We studied the association between endemism and plant life form, comparing environmentally similar areas of the fynbos region and Aljibe. We also compared the patterns of variation of species richness, endemism and taxonomic singularity in fynbos and Aljibe heathland woody communities along similar soil fertility gradients. The general aim of this study was to detect similarities between these two mediterraneanclimate vegetation types in their patterns of biodiversity.

\section{Methods}

Sites

To carry out a comparative analysis relating endemism to plant life form at the flora level, two areas with similar environmental features were selected: the Cape Peninsula in the fynbos region ('Cape') and the Sierras de Algeciras ('Algeciras') in the Aljibe Mountains (Fig. 1).

The Cape Peninsula is a rugged area of $470 \mathrm{~km}^{2}$ that reaches a maximum altitude of $1085 \mathrm{~m}$ a.s.l. The Sierras de Algeciras is also a rugged area (ca. $123 \mathrm{~km}^{2}$ ), reaching an altitude of $839 \mathrm{~m}$ a.s.l. Substrata are mainly acid sandstone in both areas, producing nutrient-poor, sandy soils. Climates are mild mediterranean with mean annual rainfall ranging from 500 to ca. $1500 \mathrm{~mm}$ in the Cape and from 954 - 1315 mm in Algeciras. The Cape Peninsula flora includes 2004 native species of vascular plants (T. Trinder-Smith unpubl.) while that of Algeciras comprises 655 species (Gil et al. 1985).

The major vegetation-type of the Cape Peninsula is fynbos. There is also some afromontane forest in fireprotected gorges and ravines and subtropical thicket confined to coastal areas. Shallow soil hilltops and ridges in Algeciras are covered by heathland, which is replaced by cork-oak woodland with a heath understorey on middle slopes. Deep humid valleys, gorges and ravines are covered with semi-deciduous oak and riparian forests.

The Cape Peninsula is, to some extent, the core of the fynbos region and represents a model of plant diversity patterns (Simmons \& Cowling 1996). Algeciras represents a similar core for Aljibe, a unique region compared with the dominant features in the Mediterranean
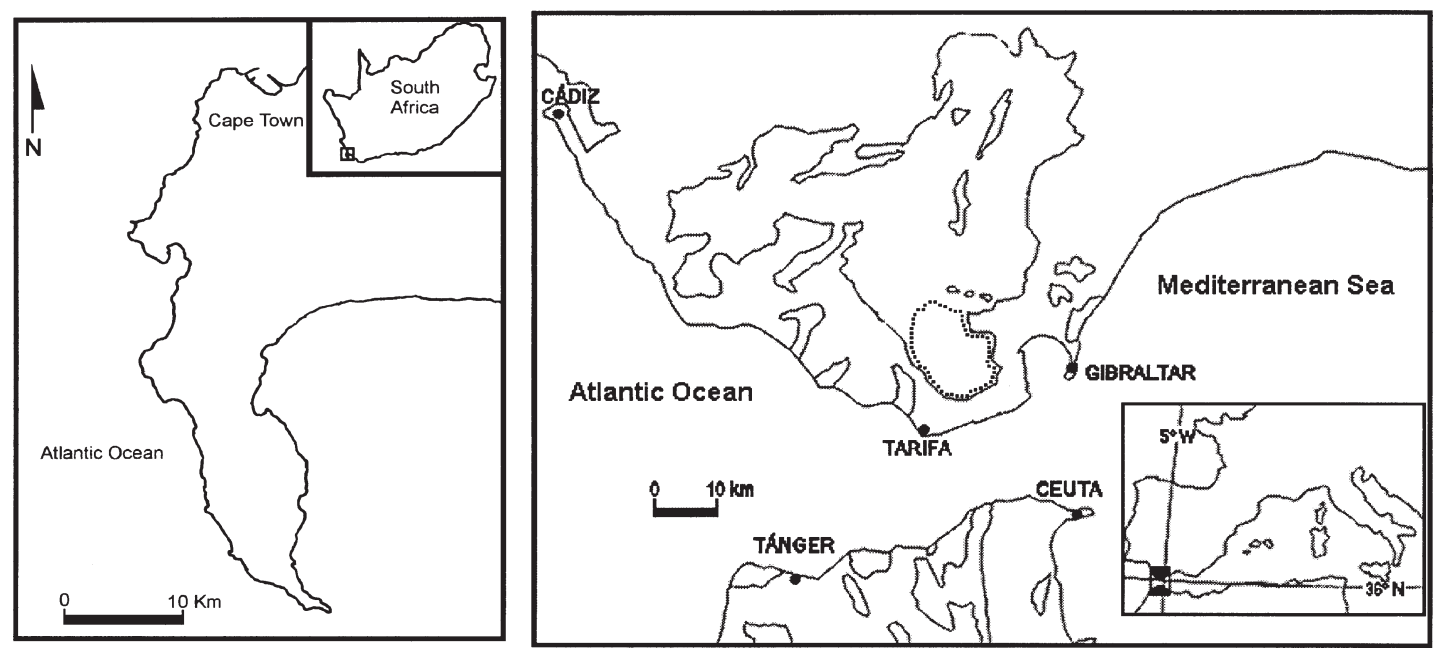

Fig. 1. Study areas. Cape Peninsula on the left. Solid lines in the right-hand map indicate the Aljibe sandstone formations in the Strait of Gibraltar, which have formed the Aljibe Mountains (Ojeda et al. 2000a). The dotted line indicates the Sierras de Algeciras. 
Basin, as described above (see also Ojeda et al. 2000a). In order to ascertain this singularity, and validate possibly similar patterns between the regions, two non-acid, similar elevation range, neighbouring sites to Aljibe, for which floristic checklists were available, were analysed as contrasts. These sites were the Subbaetic Mountains of Sevilla and Sierra de Mijas in Málaga. The first site is a mountain chain, up to $1129 \mathrm{~m}$ a.s.l., ca. $90 \mathrm{~km}$ north of Algeciras and less than $25 \mathrm{~km}$ north of Aljibe's northernmost limit. It is formed mainly of marl and limestone, common substrates in the Mediterranean Basin. The second site, Sierra de Mijas, is a small coastal mountain locality ca. $70 \mathrm{~km}$ east of Algeciras, with dominant substrates of limestone, dolomite, and serpentine and a maximum altitude of 1150 m a.s.l.

\section{Endemism and plant life form}

To carry out this comparative analysis we used the following floristic checklists: T. Trinder Smith's (unpubl.) for the Cape, Gil et al. (1985) for Algeciras, Ruíz de Clavijo et al. (1984) for the Subbaetic Mountains and Pérez-Sanz et al. (1987) for the Sierra de Mijas. We recognized four life forms: annual, perennial herb, shrub and tree. Vines were considered as shrubs or perennial herbs depending on whether or not they were woody vines. To authenticate each species' life form we used Bond \& Goldblatt (1984) for the Cape and Valdés et al. (1987) and herbarium information for Algeciras, Subbaetic Mountains and Sierra de Mijas. Pteridophytes and exotic species were excluded from the analyses. Cape species with geographical ranges restricted to the southwestern Cape floristic region (Linder 1991; Goldblatt 1997; Ojeda 1998) were labelled as endemics. Endemic species in Algeciras, Subbaetic Mountains and Sierra de Mijas were those restricted to the southwestern-Iberian and Tingitanian (Tanger) region (Ojeda et al. 1995).

Data were arranged in contingency tables for analysis. The existence of an association between endemism and plant life form in each region was tested under the Independence Model and using Pearson's $\chi^{2}$ (McPherson 1990). When evidence of association between the two variables was detected, standardized residuals were computed. Standardized residuals with a magnitude exceeding 2.0 are suggestive of observed frequencies substantially different (higher or lower) from the values expected under the Independence Model (McPherson 1990: p. 479).

\section{Biodiversity patterns in woody plant communities}

We used 47 woody community samples from the Cape and 31 samples from Aljibe. Samples from the Cape were randomly chosen from Simmons \& Cowling's (1996) 836 plots. Fifty samples were originally selected, but two cliff and one wetland community samples were discarded. Plot sizes ranged from 25 to $100 \mathrm{~m}^{2}$, total local richness was recorded in each plot (Simmons \& Cowling 1996). For each plot, values for woody species' cover were estimated visually.

Samples from Aljibe were those previously used by Ojeda et al. (1995, 1996, 2000a). They represent most of the woody vegetation types and environmental conditions in the area (cliff and riparian communities were not included). In each sample, linear cover of woody plant species in the shrub layer was recorded along a 100 $\mathrm{m}$ line transect.

Three components of biodiversity (species richness, level of endemism and taxonomic singularity; see Ojeda et al. 1995) were calculated for each community sample. Species richness was the number of woody species recorded. Level of endemism for each sample was the percentage of endemic species. Taxonomic singularity of a community sample was the mean value of the singularity of all the species recorded. Taxonomic singularity of a species, as a surrogate of its phylogenetic distinctness, is the inverse of the species number in that genus (Ojeda et al. 1995). In a regional study, this species per genus value is area-dependent and must be referred to a defined flora: in the case of the Cape samples it was obtained from the fynbos region flora (Bond \& Goldblatt 1984), for the Aljibe samples we used a floristic checklist of the Gibraltar region (A. Hampe \& F. Fernández unpubl.).

Samples were ordered separately for each region on the basis of the relative cover of their component species by means of DCA analyses (Gauch 1982). Subsequently, the samples' first DCA axis scores (first DCA axis eigenvalue being 0.963 for the Cape, and 0.809 for Aljibe) were correlated with measures of sample soil fertility. Soil fertility was estimated for each Cape plot using a simple index of decreasing fertility from 1 to 4 , where 1 was granite colluvium or shale derived soils; 2, PlioPleistocene coastal sands; 3 , recent dune sands or sandstone derived colluvium soils; and 4, leached sands derived from sandstone (Simmons \& Cowling 1996). For Aljibe samples, we used soluble aluminium content in the soil as a surrogate of decreasing fertility (see Ojeda et al. 1995, 1996, 2000b). The first DCA axis scores correlated significantly and negatively with the decreasing soil fertility index for Cape samples (Spearman- $\mathrm{R}=-0.58 ; t_{45}=$ $-4.79 ; P<0.0001)$ and with soluble aluminium content in the soil samples from Aljibe (Pearson- $\mathrm{R}=-0.53 ; F_{1,29}$ 
= 11.48; $P<0.0025$; aluminium content log-transformed). This enabled us to interpret the first DCA axis as a soil fertility gradient for both sites.

For both sets of samples, first DCA axis scores were ranked and divided into three even-sized groups to give three levels of soil fertility gradient. In so doing, we were provided with three levels of each fertility gradient matched in ranking between the Cape and Aljibe. This enabled a comparison between the two regions along the fertility gradient regarding species richness, endemism and taxonomic singularity. We applied a two-way ANOVA where both region and fertility gradient level represented fixed treatment effects. The interaction between these two effects allowed us to determine whether differences in the values of these three parameters between the fertility gradient levels are maintained across regions (Zar 1996). In other words, if convergence in the patterns of variation of these biodiversity components at the community level may exist between both regions. The taxonomic singularity variable was log-transformed to satisfy ANOVA assumptions.

\section{Results}

\section{Endemism and plant life form}

The frequency of endemic species (30\%) was significantly higher (Pearson- $\chi_{[1]}^{2}=81.0 ; P<0.0001$ ) in the Cape flora than in the Algeciras flora $(13 \%)$. However, endemism was higher in the Algeciras flora than in the two neighbouring regions (Pearson- $\chi^{2}{ }_{[2]}=24.8 ; P<$ 0.0001; Table 1).

Regarding plant-life form, more than $30 \%$ Cape species were shrubs, whereas this percentage was barely $9 \%$ in Algeciras, $10 \%$ in Subbaetic Mountains and $14 \%$ in Sierra de Mijas. However, there was a significant association between endemism and plant life form in the Cape and Algeciras floras, but not for the Subbaetic Mountains and Sierra de Mijas (Table 2). Shrubs were over represented among endemics in both the Cape and Algeciras floras (see standardized residuals in Table 2). The marginally significant result $(P<0.1)$ for Sierra de
Table 1. Numbers of endemic taxa in the three Mediterranean regions. Computed standardized residuals are shown in brackets. See text for data sources. $*=$ total excluding pteridophytes.

\begin{tabular}{lcc}
\hline & \% Endemic taxa & Total taxa* \\
\hline $\begin{array}{l}\text { Sierras de Algeciras } \\
\text { (acid sandstone) }\end{array}$ & $12.8(3.1)$ & 655 \\
$\begin{array}{l}\text { Subbaetic Mountains } \\
\text { (marl and limestone) }\end{array}$ & $5.6(-3.4)$ & 840 \\
$\begin{array}{l}\text { Sierra de Mijas } \\
\text { (limestone and serpentine) }\end{array}$ & $10.2(0.8)$ & 530 \\
\hline
\end{tabular}

Mijas was largely the result of the large number of perennial herbs among the endemics (see Table 2).

\section{Biodiversity patterns in woody plant communities}

Species richness ranged from four to 42 woody species per plot in Cape samples, and from 10 to 25 species per line transect in Aljibe. The two-way ANOVA detected significant differences between the regions but not among levels of the soil fertility gradient (Table 3 ). Aljibe samples had a pattern of maximum levels of species richness at the intermediate level of the fertility gradient but Cape samples had no clearly defined pattern (Fig. 2).

Up to 13 endemic woody species per plot were recorded in Cape samples compared to six in Aljibe transects. Percentage of endemic taxa in Cape community samples was significantly higher at all levels of soil fertility than in Aljibe (Table 3; Fig. 2). The patterns of variation of this biodiversity component along the fertility gradient were not significantly different between continents as shown by the absence of interaction between both factors (Table 3). In both areas, levels of endemism increased with decreasing soil fertility status (Fig. 2).

The taxonomic singularity index ranged from 0.003 to 0.35 in Cape samples and from 0.16 to 0.46 in Aljibe. Aljibe samples had significantly higher values of taxonomic singularity (Table 3 ). There were also significant differences in this biodiversity component among the three levels of the fertility gradient, being lowest in samples on poorer soils. This trend was similar in both regions (interaction $P$-value $=0.61$; Fig. 2 ).

Table 2. Summary of data and Pearson $\chi^{2}$ analysis results on the contingency tables classified by plant life form (group variable) and endemism (response variable) in the four regions. When significant association (at $P<0.05$ level) between the two variables was detected, standardized residuals were computed and are shown in brackets.

\begin{tabular}{|c|c|c|c|c|c|c|c|c|}
\hline \multirow[b]{2}{*}{ Life form } & \multicolumn{2}{|c|}{ Cape Peninsula } & \multicolumn{2}{|c|}{ Sierras de Algeciras } & \multicolumn{2}{|c|}{ Subbaetic Mts. } & \multicolumn{2}{|c|}{ Sierra de Mijas } \\
\hline & $\%$ Endemism & Total & $\%$ Endemism & Total & $\%$ Endemism & Total & $\%$ Endemism & Total \\
\hline Annual & $21.6(-2.1)$ & 199 & $7.5(-2.5)$ & 280 & 4.8 & 412 & 6.9 & 218 \\
\hline Perennial herb & $25.2(-2.7)$ & 1076 & $13.6(+0.5)$ & 295 & 7.6 & 315 & 13.7 & 219 \\
\hline Shrub & $40.7(+5.2)$ & 666 & $37.9(+3.8)$ & 58 & 3.5 & 85 & 12.0 & 75 \\
\hline Tree & $14.3(-2.2)$ & 63 & $2.9(-1.0)$ & 34 & 0 & 28 & 0 & 18 \\
\hline Pearson- $\chi^{2}$ & 61.9 & & 34.4 & & 4.1 & & 6.3 & \\
\hline$P$-value & $<0.0001$ & & $<0.0001$ & & 0.25 & & 0.097 & \\
\hline
\end{tabular}


Table 3. Two-way ANOVA results for comparisons in species richness, percentage of endemism and taxonomic singularity of the woody component between regions (Cape Peninsula and Aljibe Mountains) at three levels of soil fertility gradient. Type III sums of squares were used throughout.

\begin{tabular}{|c|c|c|c|c|}
\hline & df & MS & $F$ & $P$-value \\
\hline \multicolumn{5}{|l|}{ Species richness } \\
\hline Region $(R)$ & 1 & 183.26 & 4.59 & $<0.05$ \\
\hline Gradient level $(L)$ & 2 & 8.47 & 0.21 & 0.81 \\
\hline Interaction $(R \times L)$ & 2 & 70.52 & 1.77 & 0.18 \\
\hline Error & 72 & 39.92 & & \\
\hline \multicolumn{5}{|l|}{$\%$ Endemism } \\
\hline$R$ & 1 & 794.66 & 8.19 & $<0.01$ \\
\hline$L$ & 2 & 2153.51 & 22.19 & $<0.0001$ \\
\hline$R \times L$ & 2 & 2.63 & 0.03 & 0.97 \\
\hline Error & 72 & 97.06 & & \\
\hline \multicolumn{5}{|c|}{ Taxonomic singularity } \\
\hline$R$ & 1 & 0.1046 & 184.72 & $<0.0001$ \\
\hline$L$ & 2 & 0.0102 & 17.98 & $<0.0001$ \\
\hline$R \times L$ & 2 & 0.0003 & 0.50 & 0.61 \\
\hline Error & 72 & 0.0006 & & \\
\hline
\end{tabular}

\section{Discussion}

\section{Endemism and plant life form}

The high level of endemism among fynbos floras is well established (e.g. Cowling \& Holmes 1992; Cowling et al. 1992). In Algeciras, the richest in endemic taxa of the three western Mediterranean areas examined, endemism was less than half of that in the Cape Peninsula. However, there are two shared patterns in the biological aspects of endemism between Cape and Algeciras that are worth mentioning: (1) endemism is most common on the least fertile substrata and (2) endemism is associated with the shrub growth form.

Traditionally, endemism has been associated in the Mediterranean Basin with isolation through high altitude or insularity (Favarger 1972; Arroyo \& Marañón 1990). Isolation by altitude was eliminated in our comparison by selecting areas of similar low to medium elevations. Therefore, the significant association of endemism in Algeciras compared to the other two western Mediterranean neighbour sites (Table 1) may well reflect the effect of a distinct, acidic, nutrient-poor, aluminium-rich substrate as a determinant of endemism in Aljibe heathlands (see also Ojeda et al. 1995, 1996, 2000a). Highly infertile substrata have been proposed as driving forces for speciation and endemism in other areas (Kruckeberg 1986) but were rarely suggested in the Mediterranean Basin, at least in comparison with southern hemisphere mediterranean regions (Cowling \& Holmes 1992; Cowling et al. 1994, 1996).

Furthermore, ca. $5 \%$ of the endemics in Algeciras have extremely narrow ranges, being restricted to the homogeneous, distinct Strait of Gibraltar region (Arroyo
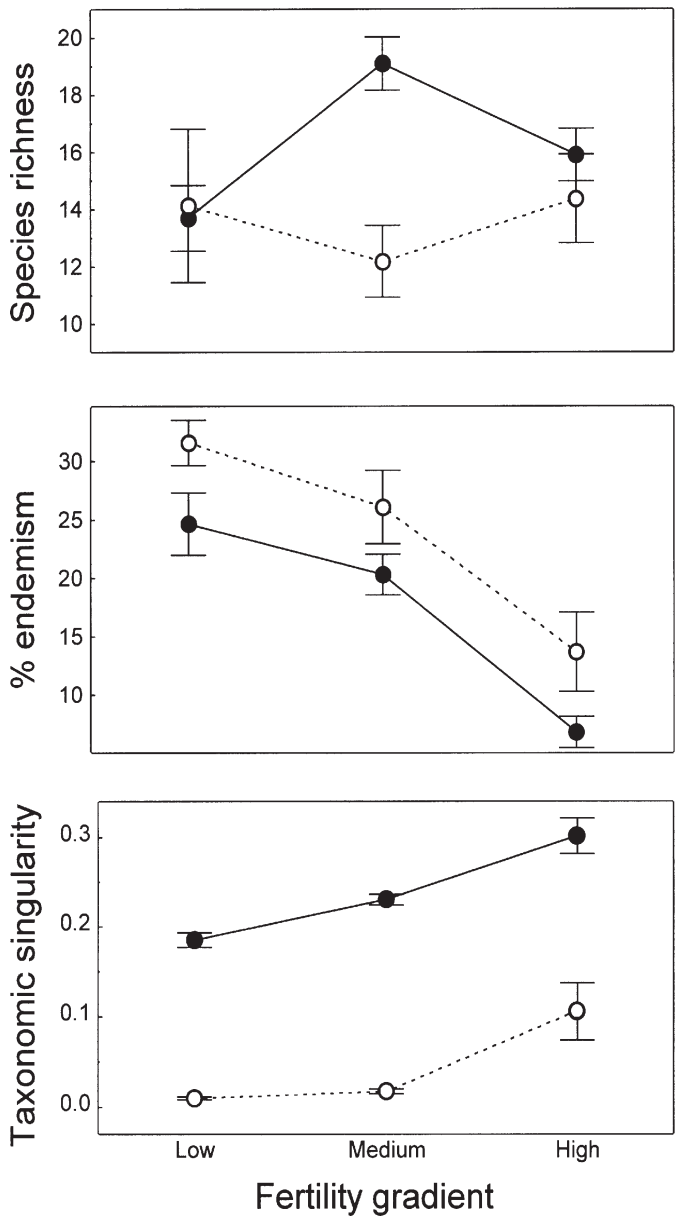

Fig. 2. Patterns of variation of three components of biodiversity - species richness, percentage of endemism and taxonomic singularity - in woody plant communities of the Cape Peninsula, CFR $(O)$ and the northern SGR $(\bigcirc)$ along an ecological gradient related to soil fertility. 
1997). This has no equivalence in the floras of the Sierra de Mijas or the Subbaetic Mountains where similar, narrow-range endemism is virtually absent.

One distinct feature of the fynbos (South Africa) and kwongan (Australia) mediterranean flora, compared to those of other mediterranean-climate regions, is the high shrub species diversity (Cowling et al. 1996). The comparatively large proportion of shrubs in the Cape Peninsula flora (33\%) was consistent with this differential feature. However, despite the similar proportion of shrub species among Algeciras (9\%) and the two neighbouring flora on non-acid soils (10\% in Subbaetic Mountains and $14 \%$ in Sierra de Mijas), endemism was significantly associated with the shrub growth form for both the Cape (fynbos) and Sierras de Algeciras (Aljibe heathlands) floristic checklists, whereas no significant association between endemism and plant life form was detected for the Subbaetic Mountains or Sierra de Mijas flora (Table 2). This association of endemism with the shrub growth form has been described for fynbos endemics (Cowling et al. 1992), but not, as far as we are aware, for any flora in the Mediterranean basin.

\section{Biodiversity patterns in woody plant communities}

The significantly higher mean species richness of the woody plant communities in Aljibe compared to the Cape (Table 3; Fig. 2), despite the renowned species richness in the latter region (Simmons \& Cowling 1996), might be an artefact intrinsic to heterogeneity in data collection. Nevertheless, Ojeda et al. (2000a) also detected a slight higher diversity in Aljibe heathland communities than in fynbos at a 0.1 -ha scale.

It is also worth noting the apparent lack of convergence in the pattern of variation of species richness along the three levels of the ecological gradient related to soil fertility (Fig. 2). Whereas Aljibe samples follow a unimodal trend that seems to fit Grime's (1979) conceptual model, Cape samples follow a different trend. Although this could also be an artefact of data collection, numerous studies have shown that it is very difficult to predict patterns of species richness ( $\alpha$-diversity) in fynbos (see Bond 1983; Cowling 1990). In fact, the dispersion in species richness values was significantly higher in Cape fynbos than in Aljibe heathland samples for the two lower levels of the soil fertility gradient (low: $Z_{\alpha(1)}=1.74, P<0.05$; medium: $Z_{\alpha(1)}=2.42, P<$ 0.01 ; high: $Z_{\alpha(1)}=1.09, P>0.10$; test of homogeneity of CVs: Zar 1996, p. 144). Cowling (1990) found no significant correlation either between $\alpha$-diversity and soil nutrient variables in lowland fynbos communities.

Percentage of endemics and taxonomic singularity comparative analyses are free from shortcomings in data collection as they are based on relative measures.
Our results show strong similarities in the patterns of variation in percentage of endemics and in taxonomic singularity along the soil fertility gradient (Table 3; Fig. 2). Fynbos and Aljibe heathlands on poorer soils are richer in endemic taxa than neighbouring communities on more fertile soils. Furthermore, they are mainly composed of species belonging to highly-diversified genera i.e. they have low average taxonomic singularity.

\section{Convergence}

Could the parallel biodiversity patterns we detected both at the regional and community levels be interpreted as outcomes of convergence between fynbos and Aljibe heathlands? A high degree of similarity between communities may not necessarily indicate convergence (Schluter \& Ricklefs 1993). Convergence studies, either at regional or community levels, must assume independence between regions, i.e. that dispersal or common ancestry do not account for the high degree of similarity (see Schluter \& Ricklefs 1993 for details). In this case, recent dispersal seems an unlikely explanation owing to the remoteness of the two areas and the barrier of the Sahara since the Eocene. Regarding common ancestry as a plausible explanation, the association of endemism with the shrub growth form detected for both fynbos and Aljibe heathland flora was not detected for either Subbaetic Mountains or Sierra de Mijas and sharing a common taxonomic pool at the genus level. There are some noteworthy examples of genera common to fynbos and Aljibe (e.g. Erica, Olea, Ilex, Polygala), although they are comparatively few and are speciesrich, widely distributed genera.

However, despite the similarities in the biological aspect of endemism at the flora level, and in the patterns of variation of two biodiversity components - endemism and taxonomic singularity - in woody communities, significant differences were detected in the levels of endemism and average taxonomic singularity. Some features of the environmental conditions and their historical course which differ between the two regions might account for these remarkable differences. For example, winter rainfall is highly predictable in the fynbos region compared to the western Mediterranean Basin (F. Ojeda et al. unpubl.). This has most probably influenced the massive speciation of some woody genera in fynbos (e.g. Erica, see Ojeda 1998) which largely accounts for the high species richness, high endemism level and low taxonomic singularity in fynbos. 


\section{Conclusion}

Despite the large amount of research on biodiversity and convergence of mediterranean-type plant communities (see review in Cowling et al. 1996), this study represents the first strong evidence for convergence in biodiversity patterns between fynbos (South African Cape) and Aljibe heathlands (Strait of Gibraltar region, western Mediterranean). It also highlights the uniqueness of Aljibe heathlands as a single vegetation-type within the Mediterranean Basin, associated with nutrient-poor, acid soils, a mild mediterranean climate regime, and presumably a mild Pleistocene. Nevertheless, it would be desirable to examine biodiversity patterns in other isolated, acidic fragments in the Mediterranean Basin. More work is needed to address the question of convergence in other traits specific to taxa and populations, such as post-disturbance regeneration behaviour as approached by Ojeda (1998) in South African Erica species.

Acknowledgements. This work was supported by a postdoctoral fellowship from the Spanish MEC to FO. It was also partially supported by Spanish DGICYT grants (PB91/ 894, PB95/551) to JA, DGES (PB97/1177) and FEDERCICYT grants (1FD97-0743-CO3-03) to TM, by the Mazda Wildlife Fund, the South African FRD and the Pew Charitable Trusts to MTS and RMC. Javier Sánchez, then Director of Los Alcornocales Natural Park, provided facilities for field work. Arndt Hampe and Francisco Fernández provided an unpublished checklist of Gibraltar plant species. The Agricultural Research Council (Pretoria), the Botanical Society of South Africa and the National Botanical Institute (Kirstenbosch) kindly provided unpublished data. Arndt Hampe, Juan Malo, Jill Rapson and an anonymous referee provided helpful comments on a previous version of the manuscript.

\section{References}

Arroyo, J. 1997. Plant diversity in the region of the Strait of Gibraltar: a multilevel approach. Lagascalia 19: 393-404.

Arroyo, J. \& Marañón, T. 1990. Community ecology and distributional spectra of Mediterranean shrublands and heathlands in Southern Spain. J. Biogeogr. 17: 163-176.

Bond, P. \& Goldblatt, P. 1984. Plants of the Cape Flora: A descriptive Catalogue. J. S. Afr. Bot. (Suppl.) 13: 1-455.

Bond, W.J. 1983. On alpha diversity and richness of the Cape flora: a study in southern Cape fynbos. In: Kruger, F.J., Mitchell, D.T. \& Jarvis, J.U.M. (eds.) Mediterranean-type ecosystems: the role of nutrients, pp. 337-356. SpringerVerlag, Berlin.

Cody, M.L. \& Mooney, H.A. 1978. Convergence versus nonconvergence in mediterranean-climate ecosystems. Annu. Rev. Ecol. Syst. 9: 265-321.

Cowling, R.M. 1990. Diversity components in a species-rich area of the Cape Floristic Region. J. Veg. Sci. 1: 699-710.
Cowling, R.M. (ed.) 1992. The ecology of fynbos. Nutrient, fire and diversity. Oxford University Press, Cape Town.

Cowling, R.M. \& Holmes, P.M. 1992. Endemism and speciation in a lowland flora from the Cape floristic region. Biol. J. Linn. Soc. 47: 367-383.

Cowling, R.M., Cartwright, C.R., Parkington, J.E. \& Allsopp, J.C. 1999. Fossil wood charcoal assemblages from Elands bay Cave, South Africa: implications for Late Quaternary vegetation and climates in the winter-rainfall fynbos biome. J. Biogeogr. 26: 367-378.

Cowling, R.M., Holmes, P.M. \& Rebelo, A.G. 1992. Plant diversity and endemism. In: Cowling, R.M. (ed.) The ecology offynbos: Nutrients, fire and diversity, pp. 23-61. Oxford University Press, Cape Town.

Cowling, R.M., Witkowski, E.T.F., Milewski, A.V. \& Newbey, K.R. 1994. Taxonomic, edaphic and biological aspects of narrow endemism on matched sites in mediterranean South Africa and Australia. J. Biogeogr. 21: 651-664.

Cowling, R.M., Rundel P.W., Lamont B.B., Arroyo M.K. \& Arianoutsou, M. 1996. Plant diversity in mediterranean climate regions. Trends Ecol. Evol. 11: 362-366.

Favarger, C. 1972. Endemism in the montane floras of Europe. In: Valentine, D.H. (ed.) Taxonomy, phytogeography and evolution, pp. 191-204. Academic Press, London.

Gauch, H.G. 1982. Multivariate analysis in community ecology. Cambridge University Press, Cambridge.

Gil, J.M., Arroyo, J. \& Devesa, J.A. 1985. Contribución al conocimiento florístico de las Sierras de Algeciras (Cádiz, España). Acta Bot. Malacitana 10: 97-122.

Goldblatt, P. 1997. Floristic diversity in the Cape Flora of South Africa. Biodivers. Conserv. 6: 359-377.

Grime, J.P. 1979. Plant strategies and vegetation processes. John Wiley \& Sons, Chichester.

Herrera, C.M. 1992. Historical effects and sorting processes as explanations for contemporary ecological patterns: character syndromes in mediterranean woody plants. Am. Nat. 140: 421-446.

Ibarra, P. 1993. Naturaleza y hombre en el sur del Campo de Gibratar: un análisis paisajístico integrado. Junta de Andalucía, Sevilla.

Kruckeberg, A.R. 1986. An Essay: The stimulus of unusual geologies for plant speciation. Syst. Bot. 11: 455-463.

Linder, H.P. 1991. Environmental correlates of patterns of species richness in the south-western Cape Province of South Africa. J. Biogeogr. 18: 509-518.

McPherson, G. 1990. Statistics in scientific investigation. Its basis, application, and interpretation. Springer-Verlag, New York, NY.

Milewski, A.V. 1983. A comparison of ecosystems in mediterranean Australia and southern Africa: Nutrient-poor soils sites at the Barrens and the Caledon Coast. Annu. Rev. Ecol. Syst. 14: 57-76.

Moll, E.J. 1991. Mediterranean vegetation in the Cape province, South Africa: a review of recent concepts. Ecol. Mediter. 16: 291-298.

Naveh, Z. \& Whittaker, R.H. 1979. Structural and floristic diversity of shrublands and woodlands in northern Israel and other mediterranean areas. Vegetatio 41: 171-190.

Ojeda, F. 1998. Biogeography of seeder and resprouter Erica 
species in the Cape Floristic Region - Where are the resprouters? Biol. J. Linn. Soc. 63: 331-347.

Ojeda, F., Arroyo, J. \& Marañón, T. 1995. Biodiversity components and conservation of Mediterranean heathlands in southern Spain. Biol. Conserv. 72: 61-72.

Ojeda, F., Marañón, T. \& Arroyo, J. 1996. Patterns of ecological, chorological and taxonomic diversity at both sides of the Strait of Gibraltar. J. Veg. Sci. 7: 63-72.

Ojeda, F. Marañón, T. \& Arroyo, J. 2000a. Plant biodiversity in the Aljibe Mountains (S. Spain): a comprehensive account. Biodivers. Conserv. 9: 1323-1343.

Ojeda, F., Arroyo, J. \& Marañón, T. 2000b. Ecological distribution of four co-occurring mediterranean heath species. Ecography 23: 148-159.

Peet, R.K. 1978. Ecosystem convergence. Am. Nat. 112: 441459.

Pérez-Sanz, S., Nieto, J.M. \& Cabezudo, B. 1987. Contribución al conocimiento de la flora de la Sierra de Mijas (Málaga, España). Acta Bot. Malacitana 12: 189-208.

Rivas-Goday, S. 1968. Algunas novedades fitosociológicas de España meridional. Collect. Bot. 8: 997-1031.
Ruíz de Clavijo, E., Cabezudo, B. \& Domínguez, E. 1984. Contribución al estudio florístico de las serranías subbéticas de la provincia de Sevilla. Acta Bot. Malacitana 9: 169232.

Schluter, D. \& Ricklefs, R.E. 1993. Convergence and the Regional Component of Species Diversity. In: Ricklefs R.E. \& Schluter D. (eds.) Species diversity in ecological communities. Historical and geographical perspectives, pp. 230-242 University of Chicago Press, Chicago, IL.

Shmida, A. 1981. Mediterranean vegetation in California and Israel: similarities and differences. Israel J. Bot. 30: 105123.

Simmons, M.T. \& Cowling, R.M. 1996. Why is the Cape Peninsula so rich in plant species? An analysis of the independent diversity components. Biodivers. Conserv. 5 : 551-573

Valdés, B., Talavera, S. \& Galiano, E.F. (eds.) 1987. Flora vascular de Andalucía occidental. Ketres, Barcelona.

Zar, J.H. 1996. Biostatistical analysis. 3rd. ed. Prentice-Hall, London.

Received 25 October 2000;

Revision received 13 July 2001;

Accepted 28 September 2001.

Coordinating Editor: G. Rapson. 